\title{
RESEARCH PAPER \\ Determination of homogeneous edaphoclimatic zones for the secondary forests of Nothofagus dombeyi in central-southern Chile
}

\author{
Carlos Esse', Pablo J. Donoso², Víctor Gerding ${ }^{2}$, and Francisco Encina- \\ Montoya $^{3}$ \\ ${ }^{1}$ Escuela de Ciencias Forestales. Universidad Católica de Temuco. Casilla 15-D, Temuco, Chile. \\ ${ }^{2}$ Instituto de Manejo de Bosques, Producción y Medio Ambiente. Universidad Austral de Chile. Casilla 567, \\ Valdivia, Chile. \\ ${ }^{3}$ Núcleo de estudios Ambientales, Facultad de Recursos Naturales. Universidad Católica de Temuco. Casilla \\ 15-D, Temuco, Chile.
}

\begin{abstract}
C. Esse, PJ. Donoso, V. Gerding, and F. Encina-Montoya. 2013. Determination of homogeneous edaphoclimatic zones for the secondary forests of Nothofagus dombeyi in central-southern Chile. Cien. Inv. Agr. 40(2): 351-360. Nothofagus dombeyi grows in a wide variety of sites in Chile $\left(30-47^{\circ} \mathrm{S}\right)$, but there is little knowledge about its productive potential. This lack of information hinders decision-making to better guide the production of goods and services from these forests. This study was conducted in central-southern Chile $\left(39^{\circ} \mathrm{S}-41^{\circ} \mathrm{S}\right)$, where this species is prominent, especially in secondary forests. The aim of the study was to determine the homogeneous edaphoclimatic zones for secondary forests of $N$. dombeyi based on the integration of environmental factors. The methodological approaches considered the spatial analysis and construction of geographic covers using geographic information systems, principal components multivariate analysis, and clustering techniques with CART analysis. Five homogeneous zones could be determined for $N$. dombeyi with a high level of accuracy. The spatial distribution of $N$. dombeyi secondary forests was explained in decreasing order by climate, soil and topography.
\end{abstract}

Key words: CART, biophysical factors, edaphoclimatic zones, k-means.

\section{Introduction}

In central-southern Chile, secondary forests dominated by Nothofagus dombeyi (Mirb.) Oerst. cover more than 200 thousand hectares (CONAF et al., 1999) between $30^{\circ} \mathrm{S}$ and $47^{\circ} \mathrm{S}$ and from sea level to approximately $1000 \mathrm{~m}$ a.s.l. These are even-aged

Received Octubre 16, 2012. Accepted July 2, 2013

Corresponding autor: cesse@uct.cl forests in the self-thinning stage of development (sensu Oliver and Larson, 1996) that originated after the occurrence of large-scale disturbances (e.g., landslides, windstorms, and fires; Donoso et al., 1999), which enabled colonization by this pioneer shade-intolerant species (Donoso et al., 2006). Trees in these forests generally have a good shape (clean and straight stems), fast growth and timber of good quality, and thus, these forests are considered economically attractive with volume 
growths of $20 \mathrm{~m}^{3} \mathrm{ha}^{-1} \mathrm{yr}^{-1}$ or more after age 20 (Donoso et al., 1999) and a rapid growth response to silvicultural interventions (Grosse and Quiroz, 1999; Donoso et al., 2006).

$N$. dombeyi occupies different sites within 10 of the 12 forest types described for Chilean forests, reflecting its adaptability to various soil conditions and climates (Donoso et al., 2006). It grows in a humid temperate climate with some dry summer spells (Donoso et al., 1999). It also grows on soils (Luzio et al., 2010) of medium to high fertility in the Intermediate Depression and Andes (andisols) and on low-fertility soils of metamorphic origin in the Coastal Range (inceptisols and ultisols). The wide variation in the site conditions in which $N$. dombeyi grows and the limited knowledge on the productive potential of these forests throughout their distribution makes it difficult to make decisions about the most convenient management prescriptions for the production of goods and services derived from these forests. According to studies by Chambers et al. (2013), Thiers (2004) and Schlatter and Gerding (1995), homogeneous areas defined by climate and soil factors are related to the growth and productivity of forest species.

The only approach used for the determination of site quality in secondary forests of $N$. dombeyi has been the site index curves developed for a spatially restricted region by Esse et al. (2007), which has limited applications because of its local character. A study about the productivity of $N$. dombeyi secondary forests should consider the most relevant factors that determine site quality at larger spatial scales. Therefore, our objective was to identify homogeneous edaphoclimatic zones through spatial analysis and multivariate techniques of the factors of climate, soil, and topography within the regions covered by secondary $N$. dombeyi forests in central-southern Chile. This approximation has not been developed for forest analyses in Chile and has great potential for site classification once productivity variables become integrated within the defined zones.

\section{Materials and methods}

\section{Study area}

The study was conducted in the provinces of Cautín, Valdivia and Ranco in central-southern Chile (Figure 1). The climate is temperate and rainy but with a short summer dry season due to the Mediterranean influence in the region (DGF-Conama, 2006, CEPAL, 2012). Cautín is characterized by sufficient rainfall to allow continuous forest cover and a well-defined dry period from three to seven months (Schlatter et al, 1997). Valdivia and Ranco are characterized by high annual rainfall, a short dry period of 1-2 months, and a limiting temperature for some temperate species (Schlatter et al, 1995). In the Andes Range, the soil is deep to moderately deep ( $>50 \mathrm{~cm}$; Schlatter et al., 2003), and its textural classes range from coarse sandy loam to silt loam, with well to excessive drainage. In the Intermediate Depression, the soils are mostly volcanic sediments originating from different geological epochs. At low elevations in the east side of the Coastal Range, the soils are deep and have developed from old volcanic ashes deposited on the metamorphic complex. At higher elevations of the Coastal Range, the soils are shallow and derived from metamorphic rock (Luzio et al., 2010).

\section{Selection and integration of biophysical factors}

The determination of climatic and soil zones was based on the methodological approaches described by Gómez-Orea (1999), which consist of the identification of homogeneous environmental units. Based on the result obtained by Thiers (2004) for $N$. obliqua, the three factors selected for the analysis of $N$. dombeyi were climate, soil, and topography. For the climate factor, the variables recorded were the mean annual temperature, annual precipitation, maximum temperature, minimum temperature and thermal oscillation. For the soil factor, the variables were effective depth, textural class, bulk density in the first $25 \mathrm{~cm}$ of the soil, 
internal drainage and total pore volume as determined from the textural class. For the topography factor, the variables considered were slope, aspect and altitude (Table 1). The climate information was obtained from Worldclim (Hijmans et al., 2005) and complemented with data from the Ordination System of Land (SOT) (Schlatter et al., 1995) and the study of climate variability for the XXI century (DGF-Conama, 2006). The soil data were obtained from CIREN $(1999,2003)$ and Luzio et al. (2010). The percent participation of each constituent soil particle (clay, silt, sand) was obtained from the textural triangle developed by the USDA (U.S. Department of Agriculture of the United States). The topographic variables were obtained from a digital elevation model (DEM) of the satellite sensor ASTER (Advanced Spaceborne Thermal Emission and Reflection Radiometer). The integration of biophysical factors was based on spatial analysis (GIS) using ArcGIS 9.3 and ERDAS 8.7. The spatial database had information for each stand of $N$. dombeyi according to CONAF et al. (1999).

\section{Statistical analysis and spatial delimitation}

We performed an exploratory principal components analysis to identify the soil, climate and topographic variables that best explain the variability of the data set (Quinn and Keough, 2002). This selection was based on the criteria of the scree test of Cattell and Kaiser-Guttman (Quinn and Keough, 2002). With the information reduced, a cluster analysis was developed (K-means). Finally, as a complementary analysis, CART (Classification and Regression Tree) was applied using the QUEST (Quick, unbiased, efficient, statistical tree) classification type. The decision tree procedure created a classification model based on the trees and classified the cases into groups or predicted values of a dependent variable (target) based on the values of independent variables (predictors). The procedure provides validation tools for exploratory analysis and confirmatory classification (McCune, 1988; SPSS Decision Trees 17.0. SPSS
Inc., Chicago, IL, USA, 2007; Pesch et al., 2011). For statistical analyses, we used R 2.11 (R Core Team, Vienna, Austria, 2012) and SPSS 17.0 (SPSS Inc., Chicago, IL, USA, 2007). For the spatial delimitation of the resulting homogeneous zones, we used the vectorial geographic covers of the site classification system developed by Schlatter and Gerding (1995) and Schlatter et al. (1995).

\section{Results}

\section{Multivariate statistical analysis}

A total number of 205,165 polygons containing $N$. dombeyi secondary forests was included in the final analysis, which represents a total area of 173,062 ha. The principal components analysis indicated that the first three factors accounted for $64.37 \%$ of the variation $(35.71,16.68$ and $11.98 \%$, respectively) (Figure 1). The analysis identified the eight most important biophysical variables. These variables were thermal oscillation, minimum temperature, mean annual temperature and annual precipitation for climate; effective depth, internal drainage and porosity for soil; and altitude for topography.

The cluster analysis allowed the generation of five groups with maximization among the groups for each cluster. For all variables and all clusters obtained, the average values of each centroid were highly significant $(\mathrm{P} \leq 0.001)$. The greatest difference among the clusters was given in the number of observations assigned to each one. Zones 1, 2 and 3 represented $89 \%$ of the total area covered by $N$. dombeyi, which indicated that the highest concentration of stands are located in the Andean Range in the province of Valdivia and in the Intermediate Depression and foothills of the Andes in the province of Cautín. The QUEST analysis (Figure 2) showed a decision tree that allows the identification of the variables that contribute most to the classification of the five growth areas: thermal oscillation, precipitation, soil porosity and soil drainage. The reliability of 
Table 1. Ranges for each variable considered in the study.

\begin{tabular}{|c|c|c|c|}
\hline Factor & Variable and Code & Rank & Class \\
\hline \multirow[t]{26}{*}{ Climate } & Average annual temperature $\left({ }^{\circ} \mathrm{C}\right)$ & $7-9$ & 8 \\
\hline & & $9-11$ & 10 \\
\hline & & $11-13$ & 12 \\
\hline & & $13-15$ & 14 \\
\hline & & $15-17$ & 16 \\
\hline & Thermal oscillation $\left({ }^{\circ} \mathrm{C}\right)$ & $16.2-17.7$ & 17 \\
\hline & & $17.8-19.3$ & 19 \\
\hline & & $19.4-20.9$ & 20.2 \\
\hline & & $21.0-22.5$ & 21.7 \\
\hline & & $22.6-24.0$ & 23.3 \\
\hline & Minimum temperature $\left({ }^{\circ} \mathrm{C}\right)$ & $-3.4--1.74$ & -2.3 \\
\hline & & $-1.75--0.07$ & -0.8 \\
\hline & & $-0.06-1.58$ & 0.8 \\
\hline & & $1.57-3.23$ & 2.3 \\
\hline & & $3.24-4.90$ & 4.0 \\
\hline & Maximum temperature $\left({ }^{\circ} \mathrm{C}\right)$ & $16.9-18.6$ & 17.8 \\
\hline & & $18.7-20.4$ & 19.6 \\
\hline & & $20.5-22.3$ & 21.2 \\
\hline & & $22.4-24.1$ & 23.5 \\
\hline & & $24.2-26$ & 25 \\
\hline & Annual rainfall (mm) & $<750$ & 750 \\
\hline & & $750-1,550$ & 1,150 \\
\hline & & $1,550-2,550$ & 2,050 \\
\hline & & $2,550-3,550$ & 3,050 \\
\hline & & $3,550-3950$ & 3,750 \\
\hline & & $3,950-5,000$ & 4,450 \\
\hline \multirow[t]{29}{*}{ Soil } & Deep physiological soil $(\mathrm{cm})$ & $<25$ & 25 \\
\hline & & $25-50$ & 37 \\
\hline & & $50-75$ & 62 \\
\hline & & $75-100$ & 87 \\
\hline & & $100-150$ & 125 \\
\hline & & $>150$ & 150 \\
\hline & Textural classes (mm) & $<0.122$ & 0.122 \\
\hline & & $0.122-0.254$ & 0.188 \\
\hline & & $0.254-0.456$ & 0.355 \\
\hline & & $0.456-0.614$ & 0.518 \\
\hline & & $0.614-0.634$ & 0.624 \\
\hline & Bulk density in $0-25 \mathrm{~cm}$ & - & 0 \\
\hline & $\left(\mathrm{g} \mathrm{cm}^{-3}\right)$ & - & 0.74 \\
\hline & & - & 0.76 \\
\hline & & - & 0.82 \\
\hline & & - & 0.83 \\
\hline & & - & 0.88 \\
\hline & & - & 0.92 \\
\hline & & - & 1.16 \\
\hline & & - & 1.42 \\
\hline & Internal drainage & Excessive & 1 \\
\hline & & good & 2 \\
\hline & & Moderate & 3 \\
\hline & & Imperfect & 4 \\
\hline & & Poor & 5 \\
\hline & & Very poor & 6 \\
\hline & Porosity $(\%)$ & Sandy-Clay Soils & 40 \\
\hline & & Sandy Soils & 42.5 \\
\hline & & Clay Soils & 45 \\
\hline \multirow[t]{2}{*}{ Topography } & Slope $(\%)$ & $0-15$ & 7.5 \\
\hline & & $15-30$ & 22.5 \\
\hline
\end{tabular}


Table 1 continued

\begin{tabular}{ccc}
\hline Factor & Rank & Class \\
\hline & $30-45$ & 37.5 \\
& $45-60$ & 52.5 \\
& Aspect $\left({ }^{\circ}\right)$ & 75 \\
& $60-100$ & 0 \\
& $0-22.5$ & 11 \\
& $22.5-67.5$ & 45 \\
& $67.5-112.5$ & 90 \\
& $112.5-157.5$ & 135 \\
& $157.5-202.5$ & 180 \\
& $202.5-247.5$ & 225 \\
& $247.5-292.5$ & 270 \\
& $292.5-337.5$ & 315 \\
& $337.5-360$ & 349 \\
& $0-200$ & 100 \\
& $200-400$ & 300 \\
& $400-600$ & 500 \\
& $600-800$ & 700 \\
& $800-1,000$ & 900 \\
& $1,000-1,200$ & 1,100 \\
& $1,200-1,400$ & 1,300 \\
\hline
\end{tabular}

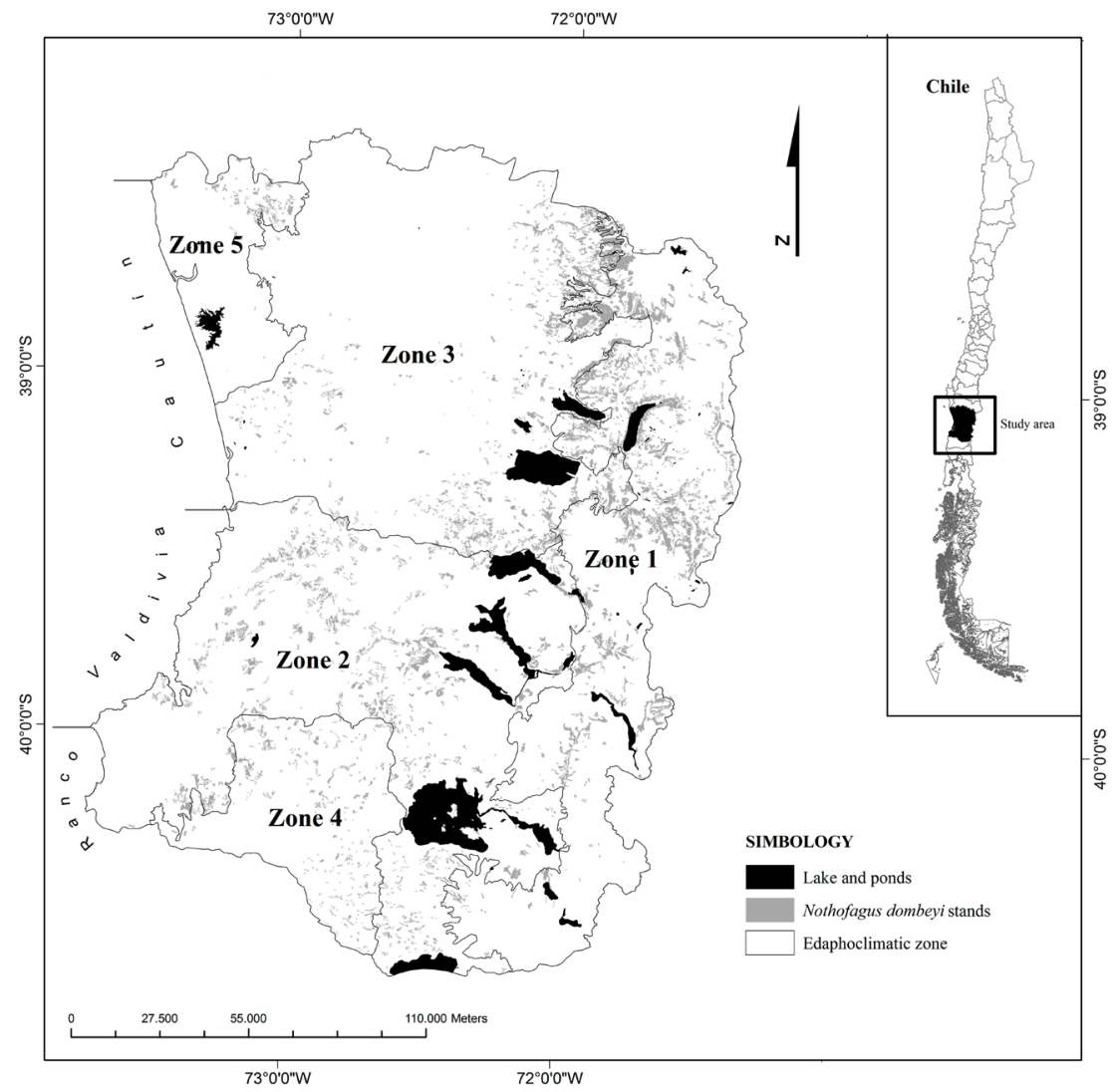

Figure 1. Edaphoclimatic zones for $N$. dombeyi determined from the integration of biophysical factors. 
the results associated with this model is shown in the confusion matrix, which revealed that the classification was $100 \%$ correct in the allocation of units to growth areas.

Zone 1 was mainly in the Andean Range across the latitudinal distribution of the study area. The area of secondary forests of $N$. dombeyi represented $32 \%$ of the total area. The factor that helped define this area was climate, with the highest annual rainfall and thermal oscillation and the lowest minimum temperature. Zone 2 corresponded to the Coastal Range, Intermediate Depression and Andean foothills in the province of Valdivia and part of Ranco. The secondary forests of $N$. dombeyi corresponded to $30 \%$ of the total area. The factors that defined this area were soil, with the lowest porosity and physiological soil depth, and topography, with lower elevations (similar to Zone 4). Zone 3 represented the Coastal Range and the Intermediate Depression in the province of Cautín, in addition to the foothills of the Andes in the southern part of the study area. This area covered $27.3 \%$ of the stands of $N$. dombeyi. The factor that defined this area corresponded mainly to climate, as represented by the highest thermal oscillation, similar to Zone 1. Zone 4 corresponded to the Intermediate Depression in the province of Ranco and accounted for $6.2 \%$ of the stands of $N$. dombeyi. The factor that defined this area was climate, with the lowest annual rainfall and the highest average annual temperature. Zone 5 was located in the Coastal Range in Cautín Province. This area comprised $5.5 \%$ of all stands. The fac-

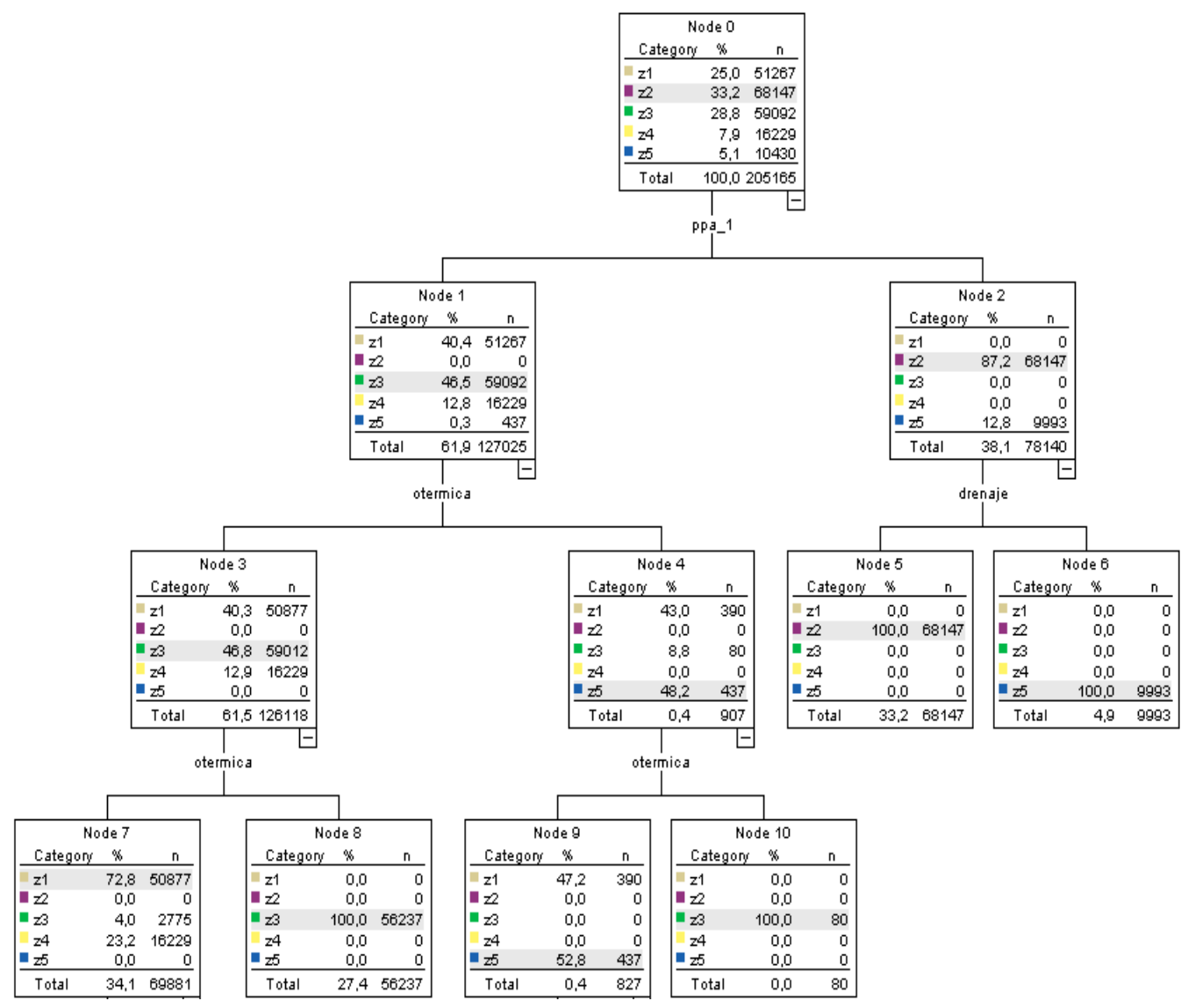

Figure 2. CART tree for the occurrence of $N$. dombeyi stands in each zone. 
tors that defined this area mainly corresponded to climate and topography, with the lowest thermal oscillation and the highest altitude (Table 2).

\section{Discussion}

The climate and soil variables selected are consistent with zoning studies for other species and sites that were based on traditional mapping techniques (Gerding and Schlatter, 1995, Schlatter and Gerding, 1995, Schlatter et al., 1995, 1997, Thiers, 2004, Cruz et al., 2009). In particular, Schlatter et al. (1997) showed that, in general, the regional climate, and more specifically the water availability, determined the growth of plant species, which is explained by their direct influence on photosynthesis and indirectly through the opening and closing of the stomata of leaves (Alberdi, 1987). Another important factor is soil moisture, which is related to soil depth and drainage (Schlatter et al., 1995). N. dombeyi has been previously reported to adapt better to areas of higher humidity, where it reaches better growth rates (Donoso et al., 2006). This study showed that the main variables that enabled the classification of different homogeneous zones of growth for stands of $N$. dombeyi were annual average precipitation, thermal oscillation and soil drainage.

Zone 1 had soils originating from volcanic ashes (inceptisols and andisols) at different stages of development (Luzio et al., 2010). This zone was characterized by the highest humidity and lowest temperature values $\left(-1.3{ }^{\circ} \mathrm{C}\right)$. These factors allowed for the permanent availability of soil moisture. The average temperature $\left(10{ }^{\circ} \mathrm{C}\right.$ or less) tended to be low for other Nothofagus species, also favoring $N$. dombeyi in this region, as reported by Weinberger and Ramírez (2001) for an elevation range from 700 to 800 m.a.s.l. At these elevations and above, $N$. dombeyi forest stands tend to be pure due to their greater tolerance to low temperatures compared with other species (Weinberger and Ramirez, 2001, Donoso et al.,

Table 2. Descriptive analysis of biophysical explanatory variables for each edaphoclimatic zone.

\begin{tabular}{|c|c|c|c|c|c|c|c|c|c|}
\hline $\begin{array}{l}\text { ZEH } \\
\text { (ha) }\end{array}$ & Statistics & $\begin{array}{l}\text { T.O } \\
\left({ }^{\circ} \mathrm{C}\right)\end{array}$ & $\begin{array}{l}\mathrm{MT} \\
\left({ }^{\circ} \mathrm{C}\right)\end{array}$ & $\begin{array}{l}\text { AAT } \\
\left({ }^{\circ} \mathrm{C}\right)\end{array}$ & $\begin{array}{c}\text { ALT } \\
\text { (m.a.s.l.) }\end{array}$ & $\begin{array}{c}\mathrm{AR} \\
(\mathrm{mm})\end{array}$ & $\begin{array}{l}\text { PSD } \\
(\mathrm{cm})\end{array}$ & DR & $\begin{array}{c}\text { POR } \\
(\%)\end{array}$ \\
\hline \multirow{4}{*}{$\begin{array}{l}1 \\
(55,339)\end{array}$} & $\min$. & 21 & -1.4 & 10 & 700 & 3250 & 62 & 1 & 40 \\
\hline & $\max$. & 23.1 & 0.1 & 10 & 1300 & 3750 & 87 & 6 & 42.5 \\
\hline & mean & 23 & -1.3 & 10 & 720 & 3656 & 85 & 1.4 & 42.3 \\
\hline & $\mathrm{CV}, \%$ & 0.6 & 30.8 & 0 & 9.6 & 1 & 9.4 & - & 1.7 \\
\hline \multirow{4}{*}{$\begin{array}{l}2 \\
(51,553)\end{array}$} & $\min$. & 19.6 & 3.5 & 12 & 100 & 2250 & 87 & 1 & 40 \\
\hline & $\max$. & 19.6 & 3.5 & 12 & 100 & 2250 & 87 & 1 & 40 \\
\hline & mean & 19.6 & 3.5 & 12 & 100 & 2250 & 87 & 1 & 40 \\
\hline & $\mathrm{CV}, \%$ & 0 & 0 & 0 & 0 & 0 & 0 & - & 0 \\
\hline \multirow{4}{*}{$\begin{array}{l}3 \\
(47,314)\end{array}$} & $\min$. & 16.6 & 1.2 & 10 & 700 & 1750 & 62 & 1 & 40 \\
\hline & $\max$ & 22.8 & 3.4 & 12 & 1100 & 2450 & 125 & 3 & 45 \\
\hline & mean & 21.9 & 2.3 & 11 & 797 & 2102 & 102.5 & 1.6 & 42.5 \\
\hline & $\mathrm{CV}, \%$ & 6.4 & 17.4 & 9 & 12.5 & 12 & 20.5 & - & 2.1 \\
\hline \multirow{4}{*}{$\begin{array}{l}4 \\
(10,786)\end{array}$} & $\min$. & 19.8 & 3.4 & 14 & 100 & 1350 & 125 & 2 & 45 \\
\hline & $\max$ & 19.8 & 3.4 & 14 & 100 & 1350 & 125 & 2 & 45 \\
\hline & mean & 19.8 & 3.4 & 14 & 100 & 1350 & 125 & 2 & 45 \\
\hline & $\mathrm{CV}, \%$ & 0 & 0 & 0 & 0 & 0 & 0 & - & 0 \\
\hline \multirow{4}{*}{$\begin{array}{l}5 \\
(8,070)\end{array}$} & $\min$. & 16.6 & 1.2 & 10 & 500 & 1200 & 62 & 1 & 40 \\
\hline & $\max$ & 20 & 2.7 & 12 & 900 & 3000 & 125 & 2 & 45 \\
\hline & mean & 18.4 & 2 & 10.5 & 809 & 1900 & 122.4 & 1.9 & 43.8 \\
\hline & $\mathrm{CV}, \%$ & 4.9 & 20 & 8.6 & 20.6 & 31.6 & 8.4 & - & 4.6 \\
\hline
\end{tabular}

T.O: Thermal Oscillation; MT: Minimum Temperature; AAT: Average Annual Temperature; ALT: Altitude; AR: Annual Rainfall; PSD: Physiological Soil Depth; DR: Drainage; POR: Porosity; CV: Coefficient of Variation. 
1999), except when it meets with $N$. pumilio at elevations $>1000 \mathrm{~m}$ (Donoso et al., 2006). With these climate and soil characteristics, $N$. dombeyi secondary stands can reach growth rates close to $20 \mathrm{~m}^{3} \mathrm{ha}^{-1} \mathrm{yr}^{-1}$ after age 20 (Donoso et al., 1999), illustrating the great growth potential of secondary forests in this zone.

Zone 2 deserves special attention. It is separated from Zone 3 due to the presence of the eastto-west mountain range of Loncoche, which is an extension of the Coastal Range that widens toward the east (Illies, 1970). This clear division illustrates the accuracy of the methodology used as both the soil and climate change in this Loncoche mountain range. The division of both zones is explained by the variation in the climate. In general, Zone 3 has a higher thermal oscillation (Table 2), which can reduce the competitive advantages of $N$. dombeyi and may explain why there were so few secondary forests of $N$. dombeyi in this zone. As a result, Zone 2 covers the Coastal Range and the Loncoche mountains, with most in the province of Valdivia, where the soils have the lowest porosity, depth and altitude range. Zone 4, in contrast to the others, showed $N$. dombeyi stands growing in areas of low rainfall and high temperatures, concentrated in the Intermediate Depression in the province of Ranco. The presence of these stands showed the ability of this species to establish and develop under various site conditions.

Zone 5 is characterized by a highly fragmented landscape with a low number of stands due to a strong land-use change to agriculture, especially since the mid-twentieth century (Camus, 2006). The stands of $N$. dombeyi were identified growing in areas of higher altitude (average $900 \mathrm{~m}$ ) and low thermal oscillation in this zone.

Several studies in Chile have proposed growth areas for various exotic and native tree species (Donoso et al., 1993, Gerding and Schlatter, 1995, Schlatter and Gerding, 1995, Echeverría and Lara, 2004, Esse et al., 2007). However, edaphoclimatic zones for native species with high silvicultural potential and an ample spatial distribution are unknown. Overall, the methods used for zoning have considered traditional mapping techniques (Schlatter et al., 1995, 1997). However, in recent years, different multivariate statistical methods have been used to reduce the variables and to identify patterns (Echeverría and Lara, 2004, Thiers, 2004, Cruz et al., 2009, Chambers et al., 2013), and hierarchical methods have been used for defining forest types and classification tree analysis (Pesch et al., 2011). This study recommends a methodology that, through the integration of biophysical factors, contributes to the determination of homogeneous edaphoclimatic zones for the potential growth of species that have a high capacity to adapt to different environmental conditions and that are economically attractive. The present study illustrates that using these techniques to determine homogeneous zones for the potential growth of economically interesting species is viable and has an ecologically reasonable explanation. These results can have relevant applications for land use allocation, as in the case of forestry for the selection of zones of homogeneous growth for differential production or conservation purposes.

\section{Acknowledgements}

C. Esse thanks the National Doctoral program CONICYT Chile and the grant 062/2011 of the Fund for Research in Native Forests administered by CONAF. PJ. Donoso thanks FONDECYT grant 1110744. F. Encina-Montoya thanks Research Directorate of Universidad Católica de Temuco and Mecesup Project UCT 0804. The authors thank professors Dr. Juan Schlatter, Dr. Oscar Thiers and Dr. Víctor Sandoval of the Universidad Austral de Chile, and Dr. Celso Navarro of the Universidad Católica de Temuco, for their helpful suggestions and comments. 


\title{
Resumen
}

\begin{abstract}
C. Esse, PJ. Donoso, V. Gerding y F. Encina-Montoya. 2013. Determinación de zonas edafoclimáticas homogéneas para bosques secundarios de Nothofagus dombeyi en el centro-sur de Chile. Cien. Inv. Agr. 40(2): 351-360. Nothofagus dombeyi crece en una amplia variedad de sitios en Chile (30-47 $\left.{ }^{\circ} \mathrm{S}\right)$, por ello existe escaso conocimiento sobre su potencial productivo. Esto dificulta la toma de decisiones que orienten de mejor forma la producción de bienes y servicios de estos bosques. Este estudio se llevó a cabo en el centro-sur de Chile (39 ${ }^{\circ}$ $\mathrm{S}-41^{\circ} \mathrm{S}$ ), donde esta especie es prominente, especialmente en bosques secundarios. El estudio tuvo como objetivo determinar zonas edafoclimáticas homogéneas para los bosques secundarios de $N$. dombeyi, basado en la integración de factores biofísicos. Los enfoques metodológicos consideraron análisis espacial y construcción de coberturas geográficas por medio de sistemas de información geográfica, análisis multivariado de componentes principales y técnicas de agrupamiento con análisis CART. Fue posible determinar cinco zonas homogéneas para $N$. dombeyi con un alto nivel de precisión. La distribución espacial de la especie se explicó en orden decreciente por los factores biofísicos clima, suelo y topografía.
\end{abstract}

Palabras clave: CART, factores biofísicos, k-means, zonas edafoclimáticas.

\section{References}

Alberdi, M. 1987. Ecofisiología de especies Chilenas del género Nothofagus. Revista Bosque (8):77-84.

Camus, P. 2006. Ambiente, bosques y gestión forestal en Chile. Santiago, Chile. p. 1541- 2005.

CEPAL, 2012. La Economía del Cambio Climático en Chile. Documento de proyecto. Comisión Económica para América Latina y el Caribe (CEPAL).Santiago, Chile. 367 pp.

Chambers, D., C. Périé, N. Casajus, and S. de Blois. 2013. Challenges in modelling the abundance of 105 tree species in eastern North America using climate, edaphic, and topographic variables. Forest Ecology and Management 291: 20-29.

CIREN. 2002. Estudio Agrológico de la IX Región. Descripciones de suelos. Materiales y símbolos. Centro de Información de Recursos Naturales (CIREN). Publicación $N^{\circ} 122$. Santiago, Chile. $360 \mathrm{pp}$

CIREN. 2003. Estudio Agrológico de la X Región. Descripciones de suelos. Materiales y símbolos. Centro de Información de Recursos Naturales (CIREN). Publicación $\mathrm{N}^{\circ} 123$. Santiago, Chile. $412 \mathrm{pp}$.
CONAF, CONAMA, BIRF, Universidad Austral de Chile, Pontificia Universidad Católica de Chile, Universidad Católica de Temuco. 1999. Proyecto Catastro y Evaluación de los Recursos Vegetacionales Nativos de Chile. Santiago, Chile. 88 pp.

DGF-Conama. 2006. Estudio de variabilidad climática para el siglo XXI. Informe Final. Departamento de Geofísica. Facultad de Ciencias Físicas y Matemáticas, Universidad de Chile. Comisión Nacional del Medio Ambiente. Santiago, Chile. 71 pp.

Cruz, P., A. Fernandez, and J. Reque. 2009. Propuesta tipológica forestal para los bosques de Quercus pyrenaica de la comarca del Bierzo del noroeste de España, empleando análisis multivariante. Revista Bosque 30(3):180-191.

Donoso, P., T. Monfil, L. Otero, L. and Barrales. 1993. Estudio de crecimiento de plantaciones y renovales manejados de especies nativas en el área andina de las provincias de Cautín y Valdivia. Cs. Inv. For. 7(2):253- 287.

Donoso, P., C. Cabezas, A., Lavanderos, and C. Donoso. 1999. Desarrollo de renovales de coihue común (Nothofagus dombeyi (Mirb.) Oerst.) Cordillera de la Costa y de Los Andes de la Pro- 
vincia de Valdivia en sus primeros 25 años. Revista Bosque 20(2):9-23.

Donoso, P., C. Donoso, B. Escobar, C. Navarro, and L. Gallo. 2006. Nothofagus dombeyi. In: Donoso, C. (ed.). Especies Arbóreas de los Bosques Templados de Chile y Argentina. Autoecología. Marisa Cúneo Ediciones, Valdivia, Chile. p. 423-432.

Echeverría, C., and A. Lara. 2004. Growth patterns of secondary Nothofagus obliqua- N. alpina forests in southern Chile. Forest Ecology and Management 195: 29-43.

Esse, C., C. Navarro, and J. Pinares. 2007. Curvas de índice de sitio para Nothofagus dombeyi en la zona preandina de la cordillera de Los Andes en la provincia de Cautín, IX Región, Chile. Revista Bosque 28(2):142-151.

Gerding, V., and J. Schlatter. 1995. Variables y factores de sitio de importancia para la productividad de Pinus radiata D. Don en Chile. Revista Bosque 16(2):39-56.

Gómez-Orea, D. 1999. Evaluación del Impacto Ambiental, Coeditan Ediciones Mundi- Prensa y Ed. Agrícola Española. Madrid, España. 22 pp.

Grosse, H., and I. Quiroz. 1999. Silvicultura de los bosques de segundo crecimiento de roble, raulí y coigüe en la región centro-sur de Chile. In: Donoso, C., and A. Lara. Silvicultura de los bosques nativos de Chile. Edit. Universitaria, Santiago, Chile. p.129-144.

Hijmans R., S. Cameron, J. Parra, G. Jones, and A. Jarvis. 2005. Very high resolution interpolated climate surfaces for global land areas. International Journal of Climatology 25(15): 1965-1978.

Illies, H. 1970. Geología de los alrededores de Valdivia y volcanismo y tectónica en márgenes del pacífico en Chile meridional. Edit. Instituto de Geología y Geografía. Universidad Austral de Chile. Valdivia, Chile. 64 pp.

Luzio, W., O. Seguel, M. Casanova. 2010. Suelos de la zona mediterránea húmeda. In: Luzio W. (ed.). Suelos de Chile. Universidad de Chile. Santiago, Chile. p. 195-239.

McCune, B. 1988. Ecological diversity in North American pines. American Journal of Botany 75:353-368.
Oliver, C., and B. Larson. 1996. Forest stand dynamics. John Wiley \& Sons, New York. p. 145-170.

Pesch, R., G. Schmidt, W. Schroeder, and I. Weustermann. 2011. Application of CART in ecological landscape mapping: Two case studies. Ecol. Ind. 11:115-122.

Quinn, G., and M. Keough. 2002. Experimental Design and Data Analysis for Biologists. Cambridge University Press. Cambridge, United England. 539 pp.

R Core Team. 2012. R: A language and environment for statistical computing. R Foundation for Statistical Computing, Vienna, Austria. ISBN 3-900051-07-0, URL http://www.R-project.org/.

Schlatter, J., and V. Gerding. 1995. Método de clasificación de sitios para la producción forestal en Chile. Bosque 16(2):13-20.

Schlatter, J., Gerding, V., and Huber, H. 1995. Sistema de Ordenamiento de la Tierra. Herramienta para la planificación forestal aplicado a la X Región. Serie Técnica. Facultad de Ciencias Forestales, Universidad Austral de Chile, Valdivia. $33 \mathrm{pp}$.

Schlatter, J., Gerding, V., Adriazola, J. 1997. Sistema de Ordenamiento de la Tierra. Herramienta para la planificación forestal aplicado a las Regiones VII, VIII y IX. Serie Técnica. 2nd ed. Facultad de Ciencias Forestales, Universidad Austral de Chile, Valdivia. $91 \mathrm{pp}$.

Schlatter, J., R. Grez, and V. Gerding. 2003. Manual para el reconocimiento de suelos. Tercera edición. Facultad de Ciencias Forestales, Universidad Austral de Chile, Valdivia, Chile. 114 pp.

SPSS Inc. 2007. Statistics Base 17.0 User's Guide. Chicago, IL, USA. 616 pp.

Thiers, O. 2004. Roble (Nothofagus obliqua) Sekundärwälder in Zentral- und Südchile: Bestimmung der für die Bestandesproduktivität wichtigen Standortsfaktoren.Freiburger Bodenkundliche Abhandlungen. Heft. 42:170.

Weinberger P., and C. Ramírez. 2001. Microclima y regeneración natural de Raulí, Roble y Coigüe (Nothofagus alpina, N. obliqua y N. dombeyi). Revista Bosque 22:11-26. 